\title{
Repoliticizing Depoliticization: Theoretical Preliminaries on some Responses to the American Fiscal and Eurozone Debt Crises
}

\section{Bob Jessop}

This article explores depoliticization in relation to the three domains of polity, politics, and policy, distinguishing its different meanings in these three contexts, identifying different strategies of depoliticization corresponding to each domain, and exploring their interconnections. Politicisation and repoliticization can be explored in the same manner. The analysis is illustrated from the strategies of depoliticization pursued in relation to the fiscal cliff debate in the USA and the constitutionalization of the Fiscal Compact in the Eurozone, Some general conclusions are also offered.

This is pre-copy-edited version of a paper in Policy \& Politics, 42 (2), 207-23 http://dx.doi.org/10.1332/030557312X655864

Introduction

Politicisation, depoliticization, and repoliticization are basic and interrelated concepts in political analysis. They may also describe specific political strategies in relatively stable, turbulent or crisis-prone periods or concrete conjunctures. This article aims to clarify the chameleon-like concept of depoliticization by distinguishing its different levels and forms. It also applies these distinctions to two cases of 'depoliticization' in the fiscal politics of the North Atlantic Financial Crisis (NAFC). The magnitude, duration, and depth of this crisis have prompted an intriguing mix of de- and repoliticisation strategies. These are evident in the manufactured hysteria about the 'fiscal cliff' in the USA and the attempts to impose technocratic government and a new economic constitution in the Eurozone. The conclusion offers some general reflections.

'Depoliticization' and cognate concepts need disambiguation. Relevant questions include whether these processes are intended outcomes of deliberate action or 
unintended, possibly unacknowledged, effects of societal trends, other processes, or practices with other goals. Depoliticization is also a relational term: it demands specific reference points in past and present political space-time against which to establish its occurrence. This means that politics and, a fortiori, politicization are polyvalent, context-dependent concepts. As Kari Palonen notes:

There are no naturally political questions, but only questions that have been politicized. Issues arise only in response to moves or processes of politicization, and only when they are thematized as contingent and controversial topics. Each of them has its own different temporal layers and contextual indexes that indicate when, how, and where they have become politicized. We may always ask whether they still carry any kind of political weight in a current situation, or whether they have been devaluated in favor of more recently politicized questions (2005: 44).

Recognizing this polyvalence helps to avoid three theoretical and analytical pitfalls:

(1) A pan-politicism that conflates politics and power, sees them everywhere, denies the specificity of the political field, and treats depoliticization as a mere change in the mode in which and/or site where [political] power operates. This can be avoided by specifying a referent for politics, e.g., open class conflict, political partisanship, issues falling within the authority of a territorial state, decisions made by those with official roles in a given political sphere, and so on.

(2) A sur-politicisme (overly political interpretation of politics) that adopts a broad definition of politics, restricts the scope of its 'other(s)', and so limits the space for politicization. However, if one sees the demarcation between the political and non-political as meta-political, then re- and de-politicization can be defined as equivalent meta-political acts despite their substantive differences.

(3) A crypto-normativity that treats one form of politics as genuine and others as inauthentic. Examples include the equation of politics with an antagonistic friend-enemy politics (Schmitt 1993), an agonistic politics of disagreement oriented to reaching and revising consensus on the common good (Rancière 2005, Mouffe 2000), a mode of freedom opposed to the state's police power 
(Arendt 1960, Castoriadis 1991), the technocratic administration of things (utilitarianism), and so on.

To move beyond these pitfalls one can build on the well-known distinction between polity, politics, and policy (e.g., Heidenheimer 1986, and, for global politics, Lipschutz 2005). This conceptual triplet can be read as highlighting the ontological depth of the political and, hence, different levels where depoliticization occurs; or, following Palonen (2000), as indicating changed meanings over centuries of the concept of the political. Choosing the first reading, I consider the entanglement of three levels of depoliticization. The constitution of the polity (constitutive politics) affects unevenly capacities to engage in politics (to influence, as Lasswell (1936) put it, 'who gets what when and how') and this in turn constrains the range of feasible policies (policymaking as an art of the possible). Yet some policies transform constitutive politics (witness the depoliticizing aim of neoliberal policies or the politicizing effects of the feminist claim that the personal is political) and reshape political practices (e.g., changing the balance of forces and stimulating new political claims and movements).

Polity (from the Greek politeia) is a spatial concept. It contrasts the sphere of society in which political activities occur with other, non-political spheres, such as religion, the economy, law, education, or science. Relevant spatial metaphors here include: sphere, domain, realm, field, area, arena, stage, scene, and site (Palonen 2000). 'Polity' covers the institutional architecture of the political field, including its boundaries and boundary-maintenance vis-à-vis non-political spheres, and the asymmetric effects of this architecture on political practice. Key issues include the institutional specificity of the polity (its disembedding from society and/or its particularization vis-à-vis other institutional orders), the separation of powers, the distinctiveness of political rationality and calculation, the structuring of the political field in normal states and exceptional regimes, differences among these regimes, and issues of scale (e.g., parish government vs global governance).

Politics refers to formally instituted, organized or informal practices that are directly oriented to, or otherwise shape, the exercise of state power. In contrast to the presumed relative stability of the polity as an instituted space, politics refers to dynamic, contingent activities that take time. They may occur within the formal 
political sphere, at its margins, or beyond it. Relevant political activities range from practices to transform the scope of the political sphere, define the state's nature and purposes, modify the institutional integration and operating unity of the state, exercise direct control over the use of state powers, influence the balance of forces inside the state, block or resist the exercise of state power from 'outside', or modify the wider balance of forces that shapes politics as the art of the possible. Key issues include the forces involved in different political activities, which issues get thematized as legitimate topics of state action and political mobilization, who defines the conditions for declaring a state of exception, and shifts in the political conjuncture.

Policy concerns the overall strategic line of the state, the changing responsibilities of branches and tiers of government, specific modes and fields of state intervention and non-intervention, the aims and content of particular decisions and non-decisions, and so on. All three Ps have institutional (structural) and practical (strategic) features that also interact (on the underlying approach that informs this analysis, see Jessop 2002, 2007). The following remarks explore re- and de-politicization at each level of analysis and their interactions. Table 1 summarizes these remarks.

\section{Depolitization and the Polity}

The identity of the polity involves material and discursive boundaries between the state qua institutional ensemble and other institutional orders or 'civil society'. At stake is the construction of the political sphere as the reference point for political projects and activities. The 'public-private' distinction is a key, socially constituted dividing line here but is also problematic (e.g., the claim that the personal is political). Polities are nonetheless articulated to other institutional orders, civil society, and informal social practices.

For example, from an institutionalist perspective, Mitchell proposes:

[t]he state should be addressed as an effect of detailed processes of spatial organization, temporal arrangement, functional specification, and supervision and surveillance, which create the appearance of a world fundamentally divided into state and society. The essence of modern politics is not policies 
formed on one side of this division being applied to or shaped by the other, but the producing and reproducing of this line of difference (1991: 95).

These processes also divide the globe into different states and societies, creating a segmented and stratified inter-state system in an emerging world society. This is more complicated than suggested by conventional accounts of the traditional Westphalian national territorial state. This is visible in the variable coincidence of different boundaries, borders or frontiers of action and the changing primacy of different scales of political action. This involves in turn various multi-spatial government and governance arrangements. It also invites reflection on whether the three Ps denote and connote the same in foreign, trans-, supra- or inter-national politics as they do in the sphere of domestic, internal politics.

Likewise, from a governmentality perspective, Foucault notes:

it is likely that if the state is what it is today, it is precisely thanks to this governmentality that is at the same time both external and internal to the state, since it is the tactics of government that allow the continual definition of what should or should not fall within the state's domain, what is public and what private, what is and what is not within the state's competence, and so on. So, if you like, the survival and limits of the state should be understood on the basis of the general tactics of governmentality (2008: 109).

This poses important issues of statecraft understood not just as the exercise of sovereign power (its conventional referent) but as the complex art of 'governance of governance' within and beyond the (changing) formal boundaries of the state. Foucauldian scholars study problem-definition, power asymmetries, domination and the political effects of specific modes of calculation, institutional assemblages, and social practices. A key aspect of governmentality is how it (re-)defines some issues as private, technical or managerial, removing them from overtly political decisionmaking and contentious politics (Miller and Rose 2008). Repoliticization could also be seen in terms of governmentality.

Lastly, from his distinctive Marxist perspective, Gramsci remarked that: 
the general notion of the State includes elements which need to be referred back to the notion of civil society (in the sense that one might say that the State $=$ 'political society + civil society', in other words, hegemony armoured with coercion') (1971: 263).

Gramsci studied the state as a complex social relation that articulates state and nonstate institutions and practices around particular economic, political, and societal projects and strategies. He emphasized the centrality of private institutions, organizations, and movements in state power, the formation of political alliances, and disorganization of subaltern forces. 'Civil society', a domain of ostensibly 'private' associations, was an integral part of the state and, a fortiori, of politics and policy. This insight has been extended to 'global civil society' and its role as a vector of de- and re-politicization in global governance practices such as development aid.

Combining Foucauldian and Gramscian perspectives, and mindful of Mitchell's remark that the essence of modern politics is the reproduction of the inherently flexible boundary between state and society, I suggest that 'the state in its inclusive sense' can be defined as 'government + governance in the shadow of hierarchy'. Thus the exercise of state power involves both state capacities unique to the state (e.g., its constitutionalized monopoly of organized coercion, tax powers, and legal sovereignty); and modes of governance or governmentalization that operate beyond the state. Government and governance are often linked through contested practices of collibration, i.e., the rebalancing of forms of governance both within and beyond the state. Such practices involve not only specific political and/or policy outcomes in particular political and policy fields but also their broader effects on state capacities. They modify the available mix of government and governance techniques and change the balance of forces. Those engaged in metagovernance may redraw the inherited public-private divide, alter the forms of interpenetration between the political system and other functional systems, and modify the relations between these systems and civil society in the light of their (perceived) impact on state capacities. While collibration is one of the state's main meta-political activities, an activity where it has a privileged strategic position, it is often hotly contested because of competing 
meta-governance projects. And, as neoliberalism indicates, these projects can originate outside the state, even if state action is needed to realize them.

For the polity, then, a key aspect of re- and de-politicization is the redrawing of the 'lines of difference' between the political and one or more ostensibly non-political spheres - whether the latter are defined as an unmarked residuum in terms of their location outside the political sphere (e.g., state vs society, public vs private) or as marked spheres with their own institutional order, operational logics, subjects, and practices (e.g., the religious, economic, legal, educational, or scientific fields). Thus politicization extends the frontiers of the polity (penetrating or colonizing the nonpolitical as an unmarked sphere or one or more marked spheres and subordinating it/them to political factors, interests, values, and forces), depoliticization rolls these frontiers back, and repoliticization reintegrates depoliticized spheres into the political.

For terminological clarity, in line with the three Ps, we can describe these processes in terms of politization. This involves constructing a division between the political and non-political spheres and locating social relations and/or sets of social issues on one or another side of this divide. This creates space for various kinds of depolitization, e.g., sacralization, marketization, juridification, scientization (expertise) or, in Foucauldian terms, governmentalization and self-responsibilization through disciplinary or governmental practices. However, as Mitchell, Foucault, and Gramsci, in their different ways, emphasize, this dividing line is not natural, even if it is sometimes taken-for-granted: it must be policed and can be repoliticized. Thus depolitization would backfire if it provokes controversies and contention about the demarcation of the political and non-political spheres and what properly belongs on the unmarked side or in a given, positively demarcated, non-political sphere.

A secondary aspect of depolitization is the reorganization of the division of political labour within the polity. This can occur through institutional differentiation, dedifferentiation, adding new tiers or scales, or moving particular topics across its branches and departments. The 'normal' forms of politics vary across branches of government: for example, partisan and adversarial politics in legislatures, concern with the 'national interest' - if only as a legitimation - in the political executive, rational-legal administration in bureaucracies, formal legal reasoning in courts, and 
constitutional interpretation in supreme courts. The resulting checks and balances and countervailing powers may contribute to depoliticalization by setting limits to politics as the art of the possible and/or introducing frictions and delays into the political process when major changes are sought. These very checks and balances can also be means of overt or covert politicalization. This can occur when administrative or judicial offices or key positions on quangos are allocated through a spoils system or, again, when bureaucrats do not act as good, Weberian officials sine ira et studio (without anger or enthusiasm) but have their own personal, partisan, or sectional political agendas (Peters and Pierre 2004). Likewise, for regulators, the co-production of regulation with input from the regulated can create regulatory capture or willing submission to sectors that might offer lucrative future employment.

More generally, moving issues across branches can change the form of politics, involving both de- and re-politicization, diminishing the significance of the prior form and boosting the importance of the stakes and practices associated with the branch to which deliberative and/or decision-making powers are transferred. Jumping scale can also produce politicization if it removes issues from a contentious to noncontentious arena or, at least, one where the stakes and balance of forces are different. Overall, this secondary aspect, in its various guises, sometimes involves politization of previously non-political spheres (e.g., education, gender relations, science), sometimes re-allocates political responsibilities across government branches, and sometimes shifts their scale (e.g., from local to national to trans- or supra-national). Adjusting the polity's variable geometry need not modify the forms of politics but may simply alter its forms, terrains, or temporal horizons.

A key issue here is the territorialization of political power. If statehood is defined in part in territorial terms (as many traditional state theories claim), then depoliticization can refer to destatization and/or depolitization. The former removes issues from the purview of a territorial state - whether in the guise of electoral politics, legislative deliberation, executive decision, bureaucratic administration, or judicial determination - and moves them into an ill-defined political sphere where 'stakeholders' or 'social partners' deliberate and negotiate about societal steering in areas of mutual interest. This preserves a space for 'politics without (official) policy-making'. Destatization is 
also described as a movement from government to governance. This trend may reflect demands by social forces dissatisfied with state and market failure and/or initiatives by state managers to supplement or replace more traditional forms of topdown government to better serve relevant 'publics'. In this sense, governance straddles the conventional public-private divide and may involve 'tangled hierarchies', parallel power networks, or other linkages across tiers of government and/or functional domains. However, just as markets and the state fail in their own ways, governance networks have their forms of failure. This opens space for the reentry of the state as a political subject charged with meta-governance responsibilities. However meta-governance is also failure-prone, thanks to the 'wicked complexity' of some governance problems and the inevitable triple politicization of the state qua institutionally-mediated material condensation of a shifting balance of forces (Meuleman 2008; Jessop 2011).

\section{Depoliticalization and Politics}

If politics refers to formally instituted, organized or informal practices that are directly oriented to, or otherwise shape, the exercise of state power, then politicization refers to the thematization of some issues as appropriate topics for state action. In general terms, politics refers to the forms, aims, and objects of political practice. It includes contention over the institutional architecture of the state and political sphere and struggles at a distance from the state that modify political calculation and/or views on the nature and purposes of state power. Important here is Poulantzas's point that the state's particular functions - techno-economic, narrowly political (i.e., concerned with reproducing the state apparatus and its institutional unity), and ideological or ethicopolitical - are all exercised in the light of its general task to maintain social cohesion in a class- and otherwise-divided society (Poulantzas 1973). Depoliticization in all three senses is crucial to these efforts to maintain social cohesion.

For clarity, we could refer to depoliticization in regard to politics as depoliticalization. However, whereas the polity provides a rather static, spatial referent, politics is an inherently dynamic, open-ended, and heterogeneous ensemble of political practices. Thus depoliticalization has several meanings. Relevant issues concern: (1) the forms and stakes of normal and/or exceptional politics; (2) the thematization of issues as 
controversial, negotiable, or consensual; (3) the subjective identity as well as material and ideal interests of political agents; (4) their location within, on the margins of, or at a distance from the state's institutional architecture; and (5) their positioning relative to the front- or back-stage of the political scene. Because space constraints prohibit an extended list of relevant dimensions of depoliticalization, I will provide five different examples.

First, if one regarded class interests as the key stake in politics, an important mode of depoliticalization would maintaining the separation between an economy subordinate to the logic of profit-oriented, market-mediated accumulation and a political sphere that makes decisions about the national or national-popular interest. For this dethematizes antagonistic class interests and disorganizes class forces in favour of negotiable interests rooted in economic-corporate or non-class interests. This requires, as Marx noted for an earlier period, a specific compromise. Subaltern classes should not advance from political to social emancipation; conversely, the dominant classes should not seek to return to the political status quo ante by restoring the Ancien Régime but be content that their social power has been restored (1978: 77). More generally, stable liberal bourgeois democratic politics depends on the self-limitation of what political forces thematize as political. If this institutionalized, depoliticalizing social compromise breaks down, there is the legal or factual possibility of declaring a state of economic or political emergency, suspending the rule of law, and limiting the forms, forums, spaces, and methods for expressing political resistance. In these conditions, the alleged demands of national security and/or economic recovery take precedence over 'normal' democratic politics. For national security, this can take a police-military form (military dictatorship), one-party rule (e.g., fascism), a government of national unity (suspending normal party politics), or multi-party support for emergency measures taken by the incumbent government. For economic crisis, we observe governments of national unity, rule by 'technocrats' (e.g., Spain and Greece in the Eurozone debt crisis), and externallyimposed economic, financial, and fiscal measures as the quid pro quo for outside assistance.

States of emergency also provide cover for open or covert action to weaken various political forces that oppose crisis-induced or, at least, crisis-legitimated policies. In 
addition to the recent neoliberal exploitation of crisis to cut entitlements (rather than, say, defense expenditure), this opportunity was taken in the handling of the Occupy Wall Street movement and its offshoots elsewhere, where measures were taken to delegitimate it, treat it as a terrorist organization, arrest its leaders, disrupt its activities, and block supportive media coverage. Notwithstanding such treatment, Occupy succeeded in politicizing the management of the financial crisis and popularizing the issue of growing inequality around the populist slogan of the $99 \%$ against the one per cent (for analysis of the Occupy movement and its role as a 'constituent moment' in US politics, see Tarrow 2011, Chomsky 2012, Gitlin 2012).

Second, and relatedly, the self-limitation of democratic politics can also be secured through constitutional law, which depoliticalizes the economic, political and social interests that were dominant at the inevitably highly politicized conjuncture in which a constitution is established and also consolidates this material condensation of the balance of forces by requiring special procedures to alter the now depoliticalized constitution. The separation of powers and guarantees of fundamental political, economic, and social rights contribute to this depoliticalization and, once the constitution has been taken-for-granted, it is hard to contest the strategic biases inscribed in this separation and in the specific content of fundamental rights. This is seen in the granting of significant autonomy to central banks to set interest-rate and exchange-rate policy within market constraints (mediated via forecasting based on neoclassical models, bond markets, credit-rating agencies, and so on) rather than being subject to overtly political pressures, whether from government, parties, social partners, or social movements. Analogously, a 'new constitutionalism' (Gill 1995) is creating super-protection for capital as neoliberalism is rolled out globally. This is seen in the re-scaling of quasi-constitutional protections for capitalist enterprises and their activities to the international level (removing them from the more contentious field of national politics) and the allocation of adjudication over disputes (including with states) to private tribunals, experts, lawyers, and other ostensibly non-political forums and/or figures.

Third, more modestly but sometimes as effectively, when the goal is to depoliticalize a political issue, state managers or other political agents may seek information, policy recommendations, or even decisions from ostensibly non-political figures 
(recruited from 'civil society'), retired politicians, elder statesmen and stateswomen, technocrats, allegedly bi- or multi-partisan commissions, or quasi-non-governmental organizations. Whether or not figures are considered 'above politics' depends, of course, on whether or not the politics-non-politics divide is accepted. One benefit of this tactic is that it can create cooling-off periods for controversial decisions. This is why the role of commissions of inquiry is sometimes described as taking minutes and lasting years. Corporatist arrangements may also serve to depoliticalize issues. They were often introduced to address long-term economic and social issues where complex, reciprocal interdependence requires long-term cooperation - thereby placing the relevant policy areas outside the short-term time horizons of electoral cycles and parliamentary in-fighting in the expectation (whether cognitive or normative) that the organizations involved (or at least their leaders) would act in 'non-political' ways to implement policies in the 'national interest' (e.g., wage restraint in the case of tripartite bodies). And, most recently, public-private partnership arrangements have been established to deliver policies in an efficient, effective, and economical manner (e.g., private health trusts, or charter schools as a case of public-private partnerships) and ostensibly (but not genuinely) free from state interference.

Fourth, depoliticalization can be fostered through governmentalization, i.e., creating the conditions for technocratic decision-making and/or the self-responsibilization of individuals, groups, organizations, or whole 'stakeholder groups' through adoption of specific technologies of government that rely on scientific expertise, consultants, expert systems, algorithms, metrology, ratings, bench-marking, contingent rewards for approved behaviour, and so on (on expertise, see Fischer 2009; on metrology, Barry 2002; on credit rating agencies, Sinclair 2005; on governmentalization, Miller and Rose 2008). These techniques are sometimes justified in terms of reducing government overload but they also have affinities with the neoliberal project of a lean state, which depends on flanking and supporting mechanisms to smooth the political sting of austerity politics (on the rollback, rollout, and blowback phases of neoliberalism, see Peck 2010). This approach can be read as a form of 'passive revolution': a process of transformation, absorption, and incorporation that translates contentious issues into bureaucratic or technical questions (Gramsci 1971: 115, 291). It aims to enhance the efficiencies of economic, political, and social domination 
via micro-management that penetrates the pores of an increasingly complex and intransparent social formation. It may also turn potential sources of resistance or obstruction into self-responsibilized agents of their own subordination. Although they would reject the Gramscian gloss given to these practices, Anglo-Foucauldian scholars and those interested in social studies of science have provided many examples (cf. Barry 2002; Miller and Rose 2008).

Fifth, following Husserl and Heidegger, we can refer to 'sedimentation' as a more semantic mode of depoliticalization that also applies to policies. This covers all forms of routinization that lead to a forgetting of the contested origins of political discourses, structures and processes. This gives them the form and appearance of objective facts of life. Building on this phenomenological claim, two critical discourse analysts have posited a cyclical logic that moves from politicization to sedimentation (depoliticization) to repoliticization as the contested origins of the taken-for-granted are exposed and a new round of contestation begins. Seen thus, repoliticization is a form of politicalization that refers to all forms of challenge to such objectivation, aiming to denaturalize the semiotic and material (extra-semiotic) features of what has become sedimented. Sedimentation and depoliticization are not confined to a specific 'political' domain (separate from others, however differentiated); they are contingent aspects of all forms of social life (Glynos and Howarth 2007). This thesis risks a latent pan-politicism avoidable only by stressing the discontinuous rhythms of alternating phases of sedimentation and (re-)politicization. This would highlight the shifting frontiers of the polity, the sedimentation and repoliticization of various features of the social world as accepted facts of life or as ripe for political action, and, analogously, as suitable subjects of active policy making rather than policy inertia.

\section{POLITIC \\ A comple ensembl continge contesta contentio political practices}

POLITIC continue

\section{POLICY}

A specific mode of political action, mediatec state ano governar 


\begin{tabular}{|c|c|c|c|c|}
\hline Level & Key Process & Some Different Modes & Structural Paradoxes & Strategic Paradoxes \\
\hline $\begin{array}{l}\text { POLITY } \\
\text { A distinct } \\
\text { site of } \\
\text { specific } \\
\text { (political) } \\
\text { relations } \\
\text { and action }\end{array}$ & $\begin{array}{l}\text { Politization } \\
\text { and cognates } \\
\text { Institutional } \\
\text { separation and } \\
\text { articulation } \\
\text { Different forms } \\
\text { of political } \\
\text { inclusion and } \\
\text { exclusion } \\
\text { Structuring the } \\
\text { world of states }\end{array}$ & $\begin{array}{l}\text { Primary mode: drawing } \\
\text { and redrawing lines of } \\
\text { demarcation between the } \\
\text { polity and its other(s) } \\
\text { Secondary: relocating } \\
\text { functions and tasks in a } \\
\text { given polity (e.g., forum } \\
\text { shifting, rescaling, de- and } \\
\text { reterritorialization) to alter } \\
\text { the forms and stakes of } \\
\text { politics together with their } \\
\text { structurally-inscribed } \\
\text { strategic selectivities }\end{array}$ & $\begin{array}{l}\text { The always contingent } \\
\text { separation of the political from } \\
\text { non-political sphere implies there } \\
\text { are constitutive outside(s) } \\
\text { (unmarked or marked) as a } \\
\text { precondition of political practice } \\
\text { The political sphere is never } \\
\text { completely closed because } \\
\text { political struggles overflow its } \\
\text { boundaries and because its } \\
\text { operations are materially } \\
\text { interdependent with those of } \\
\text { various non-political spheres }\end{array}$ & $\begin{array}{l}\text { Self-limitation on redrawing lines } \\
\text { of demarcation and redesigning } \\
\text { the political sphere occurs via } \\
\text { (temporarily depoliticalized) } \\
\text { constitutions that paradoxically } \\
\text { provide for their own suspension } \\
\text { or transformation. } \\
\text { Key strategic questions: who has } \\
\text { the right to declare a state of } \\
\text { emergency; and which forces, if } \\
\text { any, have the power to demand, } \\
\text { resist, or block the exercise of } \\
\text { this right? }\end{array}$ \\
\hline $\begin{array}{l}\text { POLITICS } \\
\text { A complex } \\
\text { ensemble of } \\
\text { contingent, } \\
\text { contestable, } \\
\text { contentious } \\
\text { political } \\
\text { practices }\end{array}$ & $\begin{array}{l}\text { Politicalization } \\
\text { and cognates } \\
\text { Front vs back- } \\
\text { stage of the } \\
\text { political scene }\end{array}$ & $\begin{array}{l}\text { Primary mode: defining } \\
\text { some problems or issues } \\
\text { as proper, others as } \\
\text { improper, themes of } \\
\text { political mobilization. NB: } \\
\text { identifying and naming } \\
\text { them is itself a political act }\end{array}$ & $\begin{array}{l}\text { Politics depends on separation } \\
\text { between front and back-stages } \\
\text { of politics. This enables } \\
\text { movement between open and } \\
\text { covert political action as one } \\
\text { form of re- and de-politicalization }\end{array}$ & $\begin{array}{l}\text { Mutual self-restraint as a } \\
\text { precondition for an agonistic } \\
\text { politics versus contingent } \\
\text { political benefits of } \\
\text { controversialization, polarization, } \\
\text { partisanship, theatricality, etc. }\end{array}$ \\
\hline
\end{tabular}




\begin{tabular}{|c|c|c|c|c|}
\hline $\begin{array}{l}\text { POLICY } \\
\text { A specific } \\
\text { mode of } \\
\text { political } \\
\text { action, } \\
\text { mediated by } \\
\text { state and } \\
\text { governance }\end{array}$ & $\begin{array}{l}\text { Politicization } \\
\text { and cognates } \\
\text { Government, } \\
\text { governance, } \\
\text { and collibration } \\
\text { as sites of } \\
\text { policy and its } \\
\text { co-ordination } \\
\text { Altering forms } \\
\text { and modes of } \\
\text { policy-making } \\
\text { and changing } \\
\text { policy lexicon } \\
\text { and semantics }\end{array}$ & $\begin{array}{l}\text { Primary mode: construing } \\
\text { problems or issues as } \\
\text { proper (or improper) } \\
\text { targets of official policy } \\
\text { and, given this, seeking to } \\
\text { shape, implement, or block } \\
\text { these policies } \\
\text { Secondary modes: wide } \\
\text { range of ways to shape } \\
\text { policy-making, from } \\
\text { framing issues as political } \\
\text { or politically relevant, } \\
\text { agenda-setting, advocacy } \\
\text { coalitions, log-rolling, } \\
\text { force-fraud-corruption, etc. }\end{array}$ & $\begin{array}{l}\text { Decision-making includes the } \\
\text { decision not to make a decision } \\
\text { (non-decision-making). } \\
\text { Policy-making includes not } \\
\text { having a policy, i.e., policy of } \\
\text { indifference. } \\
\text { Benign indifference expands } \\
\text { realm of freedom for exercise of } \\
\text { legal, political, and social rights } \\
\text { without harming others. Malign } \\
\text { indifference ignores crisis- } \\
\text { tendencies and negative } \\
\text { externalities (harms) that result } \\
\text { from unregulated systems }\end{array}$ & $\begin{array}{l}\text { Policies have particular manifest } \\
\text { and/or latent substantive and } \\
\text { symbolic aims but are also } \\
\text { typically formed, adopted, or } \\
\text { modified in the light of their } \\
\text { implications for overall balance } \\
\text { of forces and societal cohesion } \\
\text { Limiting politics to restricted } \\
\text { choice of policies (ignoring the } \\
\text { ties of policy problems to wider } \\
\text { structural or strategic problems, } \\
\text { including basic contradictions or } \\
\text { potential blowbacks) can } \\
\text { politicalize and politicize them - } \\
\text { at risk of eventual policy failure }\end{array}$ \\
\hline
\end{tabular}


Whereas politics concerns the overall strategic direction of the state and its 'division of policy labour', policy denotes specific fields of state intervention and abstention, decisions and non-decisions, modes of intervention, and so on. Their depoliticization occurs in the context of the results of earlier depolitization and depoliticalization. In particular, many of the modes for removing issues from open political contention can also be found in the formation of specific policies, policy-making, policy-taking, and policy-implementation. Sedimentation is a key mechanism here because it removes many taken-for-granted themes from the political field, from the scope of contentious politics, or from policy considerations. Supplementing this is thematization of some issues as non-political and some policies as non-negotiable. Conversely, and paradoxically, the highlighting of a restricted set of policy choices can also produce depoliticalization. As Wolff (2010) noted for the early stages of the North Atlantic Financial Crisis, if political debate focuses on a restricted choice of policies, it implies that the crisis (or other problems) are due to previous poor policy choices. The problem then becomes to identify the correct policy and this diverts attention from broader issues of governability, continuing contradictions, and so on.

\section{Politics and Economics in the North Atlantic Financial Crisis}

Space constraints prevent a detailed analysis of the genesis, aetiology, and course of the North Atlantic Financial Crisis (hereafter NAFC). Instead I discuss two cases of depoliticization to hint at some interrelations of the three levels of depoliticization and their limitations. The NAFC comprises a complex nexus of crises with technological, economic, financial, political, geo-political, social, and environmental aspects. Nonetheless its label is justified because it was triggered by accumulating problems generated by a hypertrophied finance-dominated economy in which fictitious money, fictitious credit, fictitious capital (and, increasingly, fictitious profits derived from control fraud) played an increasingly autonomous role outside the circuits of profit-producing capital. This was facilitated by four decades of neoliberalism that had depolitized monetary policy, interest rate policy, and regulatory policy by making central banks independent of direct government control 
and extending neoliberal policies that all point in the direction of depoliticization (Jessop 2013).

The typical neoliberal policy set comprises: (1) liberalization to promote greater market competition; (2) deregulation, based on belief in the efficiency of markets and the prudential, self-preserving instincts of companies and financial institutions; (3) privatization to roll back the frontiers of the polity in favour of the profit-oriented, market-mediated economy; (4) the introduction of market proxies in the residual state sector to favour efficient, effective, and economical delivery of public services, thereby reducing the scope for non-market logics in the public sector, especially when combined with budget cuts; (5) reductions in direct taxation on corporate income, personal wealth, and personal income - especially on entrepreneurial income - in order to encourage innovation and allow market forces rather than the state to determine national output; and (6) promoting internationalization to boost the free flow of goods and services, profit-producing investment, and interest-bearing capital and assist completion of the world market.

Each of these measures involves a paradoxical form of depolitization. They involve active state intervention to reset the boundaries between the political and the nonpolitical. In this case, however, the latter is not an unmarked residual (society) but a deliberately expanded marked sphere (profit-oriented, market-mediated economic activities). Another paradox, often remarked but always explicit in the Freiburg rather than Chicago version of neoliberalism, is the coupling of an expanded 'free market' with a 'strong state'. Ordo-liberalism would interpret the latter more in terms of robust regulation of market forces and a lean but solidaristic welfare state. In contrast, for the Chicago School, the strong state involves weak regulation for capital, a mean social security state, and a growing domestic security apparatus to pre-empt, control and punish dissent. Moreover, whenever the naïve belief in the principle of efficient markets is confounded by experience, neoliberals pragmatically endorse a state of economic emergency that authorizes state action and the creation of fiat money, issuing of public debt, or resort to more technical manoeuvres to rescue financial institutions deemed too big and/or too systemically interconnected to be permitted to fail or, indeed, simply too well-connected to be required to fail. In short, policies recently deemed improper and even reckless and, therefore, beyond the politically 
acceptable repertoire of government action are redefined as essential to the national and, indeed, global interest in 'timely, targeted, and temporary' (but by no means token) measures to recapitalize failing financial institutions, renewing business confidence, and restore capital accumulation.

\section{The Fiscal Cliff Debate}

The USA is the economic and political space where conditions favouring a severe financial crisis were nurtured (albeit not with this result in mind) and where it surfaced, initially unremarked on the political stage, then occupying centre-stage (Rasmus 2010, 2012). The US crisis passed through stages: credit crunch, liquidity crisis, some financial insolvencies, a generalized financial crisis, a recession that risked becoming an epic recession or even great depression, and, most recently, a 'public debt' crisis. The associated shifts in crisis-management and the symptoms of a 'crisis of crisis-management' (Offe 1984) exemplify the paradox of a political stagecraft that manufactures crises or controversy around some issues and thereby diverts political attention from other, perhaps more fundamental, themes, problems and crises (which are depoliticalized by default).

The roll-out phase of neo-liberalism contributed in this regard to the depolitization of economic processes and policy decisions that were once vital to the state's capacity to govern the capitalist economy. Two examples are: (1) the deregulation of banking and finance, because, allegedly, rational economic actors would always act prudently; and (2) official indifference to growing private debt even though this eventually contributed more to the U.S. financial crisis than the supposed evil of growing public debt (cutting which intensifies the economic crisis when private debt is already being deleveraged). Example two is entwined with the depoliticalization of key parts of the federal budget, namely, defence plus subsidies and tax-breaks for the corporate sector, such that mainstream political debate and mass media comment focus on the neoliberal bête noire of entitlement programmes.

These features of the political scene shaped the surreal fiscal cliff debate. This rested on cumulative and wide-ranging efforts over decades to restrict the policy options so that the need for entitlement reductions to lower public spending was 
naturalized. It also saw a political theatre around discussion of these limited options following the visible economic fear and political panic in November 2008. The fiscal cliff drama began its two-year run in 2011, produced by business lobbies, directed by fiscal hawks, and favourably reviewed by mainstream media. The script gave a key role in depoliticalization to an official commission. The leading players in the bicameral, bipartisan National Commission on Fiscal Responsibility and Reform (the Bowles-Simpson Commission) were recruited on both sides from known deficit hawks. Unsurprisingly, its blueprint for deficit reduction stoked the fiscal hysteria without ever seriously examining cuts in defence spending, ending unfunded wars, halting subsidies to a broad spectrum of corporate interests (often with large reserves, often held offshore), or restoring tax rates on the rich to Reagan era levels, even though wages have stagnated for 20-plus years and wealth inequalities match those of the roaring 'twenties. Although it did not achieve the internal votes needed to become an official report (in part because some members deemed it insufficiently radical), the blueprint fed into a carefully stage-managed drama on the wellilluminated political stage that focused on deficits and later used the widely accepted metaphor of 'fiscal cliff' to frame public debate. Meanwhile, back-stage dealings and plotting continued with a view to cutting entitlement programmes further and implementing yet more corporate tax breaks. The benefits for the rich of the latter will substantially exceed the 'harm' caused by individual tax hikes.

The spurious debate on the 'fiscal cliff' reveals an odd but powerful combination of:

(1) The sedimented depolitization of a crisis-prone, deregulated, profit-oriented, market-mediated economy that is regarded as the only economic option (with all of its implications for the scope of normal politics);

(2) political theatricalization of an adversarial play at the front of the political stage, which is applauded by a complicit mass media that has largely adopted unquestioningly the wilfully misleading fiscal cliff narrative, which serves the political occultation (depoliticalization) of the actions of a bipartisan parallel power network, representing the dominant fractions of capital, that has worked behind the scenes to facilitate cuts in entitlement programmes, roll-back the 
residual welfare state, and extend more tax benefits to big corporations and the richest individuals and families.

(3) the depoliticization of mainstream debate on the fiscal crisis by confining it to policy choices favoured by interest-bearing capital and transnational profitproducing capital, which are less likely to prevent a triple dip recession or great depression than the excluded options, rather than considering other, feasible policy options that might regenerate the economy, enhance competitiveness, improve conditions for the 'squeezed middle', and renew the war on poverty.

Depoliticization is enabled because state managers and those close to the state's inner sancta do not contest the 'free market' ideology of neo-liberalism. Even the Obama Administration, with its strong electoral mandate(s) for change and the potential political resource of public anger, rejected a popular, populist attack on 'banksters', bailed out financial institutions, and pursued fiscal austerity to protect corporate tax cuts and defence spending. With many dramatis personae recruited from the financial sector (notably from investment banks), the Obama Administration followed the fiscal cliff script, contributing to bipartisan and bicameral immobilism. The last minute enactment, on 2 January 2013, of modest tax hikes and deeper spending cuts allowed the federal government to maintain normal operations temporarily, setting the scene for renewed negotiations with higher economic and political stakes as the sequester approached. Yet the borrowing limit imposed on the Treasury that provides the background to this drama does not derive from the Constitution but is a recent convention promoted by fiscal conservatives and now so thoroughly depoliticalized that leading economic and political forces and the mainstream media accept it as the basis for the high-stakes fiscal debate.

Following political deadlock, Budget Control Act (2011) provisions triggered sequestration cuts of 10 per cent on 1 March 2013. Despite earlier doom-laden forecasts, the US economy is slowly recovering (although commentators doubt its robustness) and, more significantly, the federal budget deficit is falling, contrary to deficit scare-mongering. This suggests that the deficit hysteria was staged to pressure Congress in an election period to lock in bigger cuts before quantitative easing produced a (weak) recovery and that Obama collaborated for his own political 
ends. His proposed budget for 2014 (for approval in September 2013) confirms the obfuscated Obama-Republican remit to maintain the Bush tax cuts and defence spending at the expense of reducing Medicare and Medicaid (rejecting a modest payroll tax increase to cover prescription drugs or acting to limit their escalating, monopolistic pricing), cutting other discretionary social spending, and postponing pensions and reducing their real value. This is a major success for strategies of removing key issues from the political agenda.

\section{The Eurozone Crisis and the Fiscal Compact}

The European sovereign debt crisis (or Eurozone crisis) that became visible in 20089 and intensified in 2009-12 led via a series of failed crisis-measures to the Treaty on Stability, Coordination and Governance in the Economic and Monetary Union (or Fiscal Compact) signed by all but two member states in March 2012. When fully implemented, it will set binding limits ( 0.5 per cent of GDP) on the structural deficits in the annual budgets of individual member-states and thereby constrain national sovereignty in the field of economic policy. This illustrates another set of political strategies for depolitization, depoliticalization, and depoliticization.

Depolitization occurred stepwise during the formation of the European Union as powers were transferred to the executive at national and federal level and, notably, scale-jumping and arena-shifting moved crucial economic and financial powers to the European Commission with its close ties to economic and financial interests and well-known 'democratic deficit'. This trend was reinforced with the founding of Economic and Monetary Union and a European Central Bank, which, while formally accountable to member-states, is independent of democratic political control and concerned primarily with price stability rather than wider economic issues.

The Fiscal Compact continues this approach (including its neglect of public opinion) by removing budgetary policy from national control, establishing technical rules set by experts and premised on theoretically-flawed neoclassical economic reasoning, and triggering sanctions if the limits are broken. Precedents for this debt brake include Switzerland (2001-) and Germany (2009-), although these show that it is hard to measure structural deficits, operate the brake, and avoid political 
manipulation. Scientific validity and technical feasibility issues apart, this measure will prevent active fiscal policy along Keynesian lines. By extending disciplinary neoliberalism, it constitutionalizes and entrenches the power of capital, limiting states' political autonomy and transforming budget-making into a more technocratic process subject to legal sanctions as well as market pressures.

Depoliticalization was reinforced by the transformation of the unexpected (in official circles) financial crisis into several sovereign debt crises and contagion risks rooted in deeply interconnected European credit markets. This created the space for technocratic governance in southern member states, whether through EU and ECBinspired coups d'état (Greece and Italy) or through de facto or formal governments of national unity (Spain, Portugal). These governments are running states of economic emergency that authorize big spending cuts and neoliberal structural reforms. Yet the depth of the crisis and the impact of austerity have prompted growing resistance in the periphery from the unemployed, the poor, the marginalized, savers, etc., with a likely spread northwards. This requires careful modulation of conditionalities to keep the electorates of 'donor' states on side and to temper popular unrest that would destabilize the governments of economic emergency in the indebted states. Yet this tends to hide from public view that bailout monies largely return from the PIIGS to financial institutions in Northern Europe.

Depoliticization depends on the TINA (There is No Alternative) mantra that delimits the feasible set of economic, political, and social policies. This proved unappealing in Southern Europe (outside the current set of state managers) and is contested by post-Keynesian economists, diverse think tanks, and several major political parties when in opposition. The tipping of the Eurozone into a deepening double dip recession, which has triggered second thoughts in the International Monetary Fund and Organisation for Economic Cooperation and Development, growing popular unrest, including right-wing populist reaction and xenophobia, and popular reaction against the European Central Bank attempt to renege on deposit insurance in Cyprus all indicate the limits of depoliticization even when depolitization is still firmly entrenched. This suggests that the validity of Deutsch's dictum (1963: 111) that power means not having to learn from one's mistakes may vary across polity, politics, and policy. 


\section{Conclusions}

I identified three levels of politics and linked them to different modes of politicization, depoliticization, and repoliticization. Given this issue's focus, my remarks largely addressed depolitization, depoliticalization, and depoliticization, which correspond respectively to efforts and/or outcomes that (1) reconfigure the space of politics (the polity) to the benefit of its unmarked 'other' (society) or specific marked spheres (notably the profit-oriented, market-mediated economy); (2) change the sites and stakes of political practices (the field of politics); and (3) thematize some issues as inappropriate for political policy-making.

With consolidated neoliberal regime shifts or, at least, the ratchet-like advance of neoliberal policy adjustments in the last 30-40 years and the recent imposition of neoliberal conditionalities on the indebted PIIGS (Portugal, Ireland, Italy, Greece, Spain) economies, all three forms of depoliticization have favoured economic neoliberalism nolens volens by redrawing the boundaries, limiting the stakes, and restricting the allegedly feasible set of policy choices in the political field. This extends capital accumulation as an organizational principle towards the expanding horizon of the world market and world society.

This modifies the line between the polity and its other(s), the nature and purpose of politics, and the policies that are acceptable and feasible vis-à-vis the problemgenerating capacity of a self-expanding economic sphere. The extension of real and proxy markets; of commodification; the fictitious commodification of nature, labourpower, money and credit, and knowledge; liberalization and regulation aimed at market completion; and lower taxation - all these render the political sphere indifferent to market outcomes, removing decisions and actions with major societal repercussions from a public domain where they can be subject to contingent, contentious, and contested political practices. This was already inscribed in the institutional separation between the market economy and the state, with only the latter, if at all, subject to democratic control but it is certainly reinforced by these trends. 
It is tempting to focus on the aims of the social forces seeking to transform the polity, modify political practices, and pursue some rather than other policies. But this would mean neglecting the adequacy of their political, non-political, or apolitical construals to the social and material challenges that these forces seek to resolve. There are basic contradictions and crisis-tendencies that are incompressible and do not disappear simply because handling them is no longer deemed to fall within the political sphere, to be a proper theme of political practices, or to belong to a legitimate range of policies. As Poulantzas argued, whether or not the state intervenes, the contradictions of capitalism are inescapable (1978: 167-172). This gains credence from the eventual outbreak of the crisis of regulated, financedominated accumulation manifest in the NAFC, forcing the re-politicization of the market economy, the re-thematization of economic issues as appropriate objects of political practice, and active policy making rather than studied indifference.

\section{Acknowledgment}

Research was aided by an ESRC professorial fellowship (RES-051-27-0303). The usual disclaimers apply.

\section{References}

Arendt, H. (1960) 'Freedom and politics', Chicago Review, 14 (1): 28-46

Barry, A. (2002) 'The anti-political economy', Economy and Society, 31 (2): 268-284.

Castoriadis, C. (1991) Philosophy, politics, autonomy. Oxford: Oxford University Press.

Chomsky, N. (2012) Occupy. Harmondsworth: Penguin.

Deutsch, K. (1963) The nerves of government, New York: Free Press.

Fischer, F. (2009) Democracy and expertise, Oxford: Oxford University Press.

Foucault, M. (2008) Security, territory, population. Lectures at the Collège de France, 1977-1978, Basingstoke: Palgrave.

Gill, S. (1995) 'The global Panopticon? The neo-liberal state, economic life and democratic surveillance', Alternatives 20 (1): 1-49.

Gitlin, T. (2012) Occupy nation: The roots, the spirit, and the promise of Occupy Wall Street, New York: HarperCollins.

Glynos, J. and D. Howarth (2007) Logics of social explanation, London: Routledge. 
Gramsci, A. (1971) Selections from the Prison Notebooks, London: Lawrence \& Wishart.

Heidenheimer, A.J. (1986) 'Politics, policy and policey as concepts in English and Continental languages', Review of Politics, 48: 1-26.

Jessop, B. (2002) The future of the capitalist state, Cambridge: Polity.

Jessop, B. (2007) State power: A strategic-relational approach, Cambridge: Polity.

Jessop, B. (2011) 'Metagovernance', in M. Bevir (ed.) Handbook of Governance, London: Sage.

Jessop, B. (2013) 'Credit money, fiat money and currency pyramids', in J. Pixley and G.C. Harcourt (eds) Financial crises and the nature of capitalist money, Basingstoke: Palgrave-Macmillan.

Lasswell, H. (1936) Politics: Who gets what, when, and how. New York: Meridian $<1958>$.

Lipschutz, R. (2005) 'Global civil society and global governmentality', in G. Baker and D. Chandler (eds) Global Civil Society, London: Routledge.

Marx, K. (1978) The class struggles in France, in MECW 10, London: Lawrence \& Wishart $<1850>$.

Meuleman, L. (2008) Public management and the metagovernance of hierarchies, networks and markets, Heidelberg: Springer.

Miller, P. and N. Rose (2008) Governing the present, Cambridge: Polity.

Mitchell, T.J. (1991) 'The limits of the state: Beyond statist approaches and their critics', American Political Science Review, 85 (1): 77-96.

Mouffe, C. (2000) The democratic paradox, London: Verso.

Offe, C. (1984) Contradictions of the welfare state, London: Hutchinson.

Palonen, K. (2000) 'Two concepts of politics, two histories of a concept?' Paper presented at European Consortium for Political Research Joint Sessions of Workshops, Copenhagen 15-21 April.

Palonen, K. (2005) 'The politics of conceptual history', Contributions to the History of Concepts, 1 (1): 37-50.

Peck, J. (2010) Constructions of neoliberal reason, Oxford: Oxford University Press.

Peters, B.G. and J. Pierre (eds) (2004) The politicization of the civil service in comparative perspective. London: Routledge.

Poulantzas, N. (1973) Political power and social classes, London: NLB.

Poulantzas, N. (1978) State, power, socialism, London: Verso. 
Rancière, J. (2005) Disagreement: Politics and philosophy, Minneapolis: University of Minnesota Press.

Rasmus, J. (2010) Epic recession: Prelude to global depression. London: Pluto.

Rasmus, J. (2012) Obama's economic recovery: Recovery for the few, London: Pluto.

Schmitt, C. (1993) 'The age of neutralizations and depoliticizations', Telos, 96: 13042.

Sinclair, T.J. (2005) The new masters of capital. American bond rating agencies and the politics of creditworthiness, Ithaca: Cornell University Press.

Tarrow, S. (2011) 'Occupy Wall Street is not the Tea Party of the left', Foreign Affairs October 10, at http://www.foreignaffairs.com/articles/136401/sidney-tarrow/whyoccupywall-street-is-not-the-tea-party-of-the-left.

Wolff, R. (2008) 'Policies to "avoid" economic crises', MR Zine, 6 November. http://mrzine.monthlyreview.org/index061108.html. 